\title{
Con Dao's Geo-Economic and Geopolitical Position: Approaching From the Competition Between Western Countries (XVII - XIX Centuries)
}

\author{
Luu Van Quyet ${ }^{1} \&$ Phan Thi Anh Thu ${ }^{1}$ \\ ${ }^{1}$ University of Social Sciences and Humanities, Vietnam National University, Ho Chi Minh City, Vietnam \\ Correspondence: Luu Van Quyet, University of Social Sciences and Humanities, Vietnam National University, Ho Chi \\ Minh City, Vietnam. Tel: 84-91-828-9128.
}

Received: August 26, 2020

Accepted: October 26, 2020

Online Published: January 6, 2021

doi:10.5430/rwe.v12n1p226

URL: https://doi.org/10.5430/rwe.v12n1p226

\begin{abstract}
Thanks to the characteristics of an archipelago consisting of many small islands in the East Sea, separated from the mainland, Con Dao has a particularly essential position in politics, military, and economy for Vietnam and many countries in history and present. Due to the abundance and diversity of natural resources, it was located in an important position on international trade routes, since the middle period, Con Dao was not only a favorable place to build centers trade or transshipment warehouse linking the East with the West but also helps to link and shorten the journey to countries within Asia. In the strategic vision of Western countries (from XVII century), Con Dao is an essential point in trade activities, contributing to control and domination of the maritime route from the Pacific to the Indian Ocean as well as to ensure the exclusive right to exploit and accumulate capital in this area. Thus, in the XVII and XIX centuries, both Britain and France competed to monopolize Con Dao towards the goal of gaining an economic and political advantage in the strategy of expanding the sphere of influence outside Europe. Through the interpretation of the Western countries' competition to monopolize Con Dao, this article aims to clarify the unique geo-economic and geopolitical position of this archipelago; thereby, there is a connection between the role and position of Con Dao in Vietnam's development strategy in the current context.
\end{abstract}

Keywords: Con Dao, geo-economics and geopolitics, England-France, XVII-XIX centuries

\section{Introduction}

Historically, the name "Con Dao" (Con Dao) was derived from the Malay word "Pulau Kundur" (ie "Pumpkin Island"). This place was also known by the French as "Poulo Condor" and the Vietnamese called "Con Lon" (Kunlun) (i.e., Snake Island because of many reptiles living here). Con Dao today is situated in Ba Ria - Vung Tau province (Vietnam), $185 \mathrm{~km}$ from Vung Tau city and 230km from Ho Chi Minh City (Institute of Geography - Vietnam Academy of Science and Technology, 2010, pp. 1021-1022). While Phu Quoc has 22 large and small islands (of which the largest is Phu Quoc Island with an area of $567 \mathrm{~km}^{2}$ ) (Trần, Đ. T. (ed) 2012), Con Dao consists of only 16 islands, of which the largest is Con Dao with a mere 52km² (Institute of Geography - Vietnam Academy of Science and Technology, 2010, p. 1022). Despite its small area, Con Dao has been identified as the frontline position and plays an important role as "natural hedge" in the Southeast of Vietnam.

\subsection{Literature Review}

Due to the projections of the Asia-Europe shipping route, which connects the Pacific Ocean to the Indian Ocean, the island was known to the Western expedition early. In 1292, Italian explorer Marco Polo on his return from China to Europe set foot in this area and established the first records confirming the existence of the archipelago as a "stopover point" on the route from North to South, from East to West (Henry Yule 1921, pp. 276-277). Following Marco Polo, Portuguese navigator Fernão Perès de Andrade arrived on Con Dao in September 1516 and said European sailors frequented this place to obtain fresh water, look for sea turtles and pick up wild grapes. From the mid-60s of the XVI century, the natural geographic features of Con Dao were recorded in the draft of the "Os Lusiadas" immortal epic by Luís Vaz de Camões when his Portuguese Expedition visited that area (Nguyen, D. T; Nguyen, L. \& Ho, S. T. 2010, pp. 20-21). All records of Westerners at that time showed the natural features and favorable geographical position of Con Dao in both history and literature. This area, therefore, has long attracted the special attention of the governments of Western countries with the intention of possessing and building Con Dao to become an important commercial, politic and military base - from the XVII century. 
So far, there have been many studies on this issue from a historical perspective, such as Ban nghiên cứu Lịch sử Đảng Đặc khu Bà Rịa Vũng Tàu-Côn Đảo (The Party History Research Board of Ba Ria Vung Tau-Con Dao Special Zone). 1987. Nhà tù Côn Đảo (1862-1945) (Con Dao Prison (1862-1945)); Charles B. Maybon. 2011. Nhũng ngưòi châu Âu ở nước An Nam (Europeans in An Nam). Translated by Nguyen Thua Hy; Châu, Đ.Q. (Zhou Daguan 周達 觀). 2017. Chân Lạp phong thổ ký (真臘風土記, Notes on the Customs of Chenla); Hồ, B. T. 2019. Quân chúa Nguyễn bảo vệ biển đảo, xua đuổi người Âu Châu (Lord Nguyen Defending Seas and Islands, Driving Europeans away); Lê, H.P. 2006. Nhà tù Côn đảo (Con Dao Prison); Nguyễn, Đ. T; Nguyễn, L. \& Hồ, S. T. 2010. Lịch sử nhà tù Côn Đảo 1862-1975 (History of Con Dao Prison 1862-1975); Nguyễn, M.D. 2006. All the above works mainly introduce the history of the formation and development of Con Dao prison, about the prison regime and the struggles of prisoners. These topics are often interested by the majority of Vietnamese scholars. In reality, there are very few studies presented on Con Dao in the angle that this is an island with a unique strategic location, once a place for the scramble for the sphere of influence among major powers.

Some researches introducing the history of relations of Vietnam in the XVII-XVIII centuries and Southern Vietnam also mentioned Con Dao as: Li, T. 1998. Nguyen Cochinchina - Southern Vietnam in the Seventeenth and Eighteenth Centuries; Ithaca, N.Y. 1999: Cornell University Press. Vietnamese translation: Xú Đàng Trong: Lịch sủ kinh tế-xã hội Việt Nam thế kỷ XVII-XVIII,; Nguyễn, T. L. 2005. Bang giao Đại Việt triều Nguyễn (Dai Viet Diplomatic Relations in Nguyen Dynasty). Nguyễn, T.L. 2009. Hải Đảo ở vùng biển Tây Nam (Islands in the Southwest Sea). Phạm, X. 2012. Côn Đảo Pháo đài tiền tiêu đông nam Tổ quốc (Con Dao - Southeastern Fortress of the Nation); Phan, H.L. 2017. Vùng đất Nam Bộ quá trình hình thành và phát triển (The Southern region of the process of formation and development); Phan, K. 1969. Việt sử xứ Đàng Trong (Vietnamese History in Cochinchina); Thạch, P. Nguyen, T.M (ed). 2005. Địa chí Bà Rịa-Vũng Tàu (The Geography of Ba Ria - Vung Tau) ; Trương, B.C. 2011. Hoạt động ngoại giao của nước Pháp nhằm củng cố co sở tại Nam Kỳ (1862-1874). (French Diplomatic Activities Aimed at Strengthening the Base in Cochinchina (1862-1874)).

Besides, several researchers also began to expand the scope of research with in-depth analysis of several new topics such as Foreign trade activities, the military of the Western countries in Con Dao or the shipwrecks of the Europeans on the Vietnamese archipelago, typically as the articles: Nguyễn, M.D. 2006. Về hoạt động thuoong mại của công ty Đông Ấn Pháp với Đại Việt - nưa cuối thế kỷ XVII đến giũa thế kỷ XVIII (Regarding the Commercial Activities of the French East India Company with Dai Viet - the Second Half of the XVII Century to the Middle of the XVIII Century); Jean Paul Morel. 2010. Relation Abrégée des Voyages Fraits Par Le Sieur Poivre de 1748 à 1757; Mark W. McLeod. 1991. The Vietnamese Response to French Intervention (1862-1874); Sir Francis Drake and William Dampier. 1879. A Voyage around the World; Nguyen Duc Hiep. 2017. "The Wreck of the European in Paracel Islands"; Bruce. 1810. Annals of the Honorable East-India Company: From Their Establishment by the Charter of Queen Elizabeth, 1600, to the Union of the London and English East-India Companies, etc. The above works have presented many aspects of Con Dao, including the geo-economic and geopolitical positions of this archipelago. However, they have not been presented systematically, not clarifying the importance of the geopolitical and geo-economic position of Con Dao through the competition for influence of Western countries since the end of the XVII century. These are the large academic "gap" that authors want to fill through the content of this paper.

\subsection{Research Methodology}

On the basis of accessing documents that are Vietnamese historical collections as well as Vietnamese archives and published works of Vietnamese and foreign authors in the same research field, we define a new approach to Con Dao that uses historical research, logical method and interdisciplinary/trans-disciplinary methods to supplement the findings of previous scholars by showing a perspective comprehensively and deeply about the need to establish a trading post and build military bases of the British and French imperialists at this site.

The historical method is used in the research to reproduce the events in chronological and spatial order about the progression of the Western countries' competition influence each other in Con Dao from the XVII century to the XIX century. The events are described objectively and honestly; thereby showing the intention of both British and French imperialism in establishing trading and building military bases in Con Dao. Also, the method of comparing history by space and the method of comparing history over time are also interested in using by the authors to help the readers have a multi-dimensional view of the series of events and historical problems emerging in the effort occupation of Con Dao by foreign powers since the Middle Ages. Thus, the historical research method ensures time continuity, spatial specificity, and reasonableness in the diverse relationship with the major wars in Asia and Europe that their results affected colonialism's ability to occupy Con Dao. 
The logical method is used by the authors in analyzing the chain of events to find out the characteristics of the Western competition to occupy Con Dao. On that basis, the authors compare and make important comments on the process and results of the occupation of Con Dao - islands holding a key geo-economic and geopolitical position in Asia. Moreover, interdisciplinary and trans-disciplinary research methods are flexibly applied in the research. Knowledge of geography, economics, military, politics is harmoniously combined with historical knowledge, thereby showing the importance of geographical location to the historical fate of the land from past to present.

\subsection{Research Questions}

To complete this paper, the authors identified and asked the following research questions:

$\checkmark \quad$ Why did Western countries discover and occupy Con Dao? What was the explorers' initial perception of this place?

$\checkmark$ How did the geo-strategic position of Con Dao mean to the economic and military activities of imperialism?

$\checkmark$ Geo-economic position and geopolitics and military position of Con Dao were the reasons why England and France competed with each other to monopolize the island.

The first group of questions directed the authors to focus on researching and decoding the objective factors of the research topic (geographical location, climate, natural resources in Con Dao). On that basis, the article makes a comparison with another famous place of Vietnam (Hoang Sa archipelago/ The Paracel islands) in the XVII century.

The second group of questions is directly related to the subjective factors of the research problem (England, France, and Vietnam):

$\checkmark \quad$ Did England and France need to establish their trading posts and military bases in Con Dao? If so, what historical events were that desire manifested specifically?

$\checkmark$ How did Western countries annex Con Dao happen? Which country consistently dominated in controlling Con Dao? Why?

$\checkmark \quad$ What were the roles and responsibilities of the Nguyen Dynasty (Vietnam) in Con Dao issue?

$\checkmark \quad$ What are the basic characteristics of the process of conquering Con Dao of England and France (XVII-XIX)? At the end, which country captured Con Dao until the XX century?

$\checkmark$ How has Vietnam exploited the geo-strategic position of Con Dao in the development and integration process?

These are all interesting and challenging issues of the subject. The above research questions have been explained and analyzed in detail by the authors in this paper.

\subsection{Scientific and Practical Significances}

For nearly five centuries, Western countries found out, occupied, and exploited Con Dao (XVI-XIX), which is also a long and important historical period in Vietnam. During that time, the simultaneous presence of many powerful nations in this strategic area indicated the island's special historical place. Con Dao soon attracted the attention of Arab, Malay, Chinese navigators, and merchant ships of Italy, the Netherlands, Spain, Portugal, England, and France, especially during the period of the development of merchandise trade in the East Sea (XVI-XVIII centuries). Later, the occupation and fierce competition between French and British imperialism in Con Dao were also to monopolize this strategic trading position. The aforementioned analysis shows that Con Dao and its related problems are always closely linked to the development of Vietnamese history, at the same time as a significant influence on the history of the region and the world. From that, the research of the geopolitical and geo-economic position of Con Dao to explain the process and competitive results of Western countries (XVI-XIX) is more and more meaningful in terms of science and reality.

\section{Results}

\subsection{Geo-strategic Position of Con Dao: A Catalyst for Competition for Influence Among Western Countries From XVII Century}

\subsubsection{Geo-economic Position of Con Dao}

Historically, Con Dao had been seen as the primary "trade gateway", the most suitable area to build trade centers or cargo transshipment storage points between the East and the West. Characterized by an archipelago covering many small islands in the East Sea (Note 1), separated from the mainland and located on the journey from the Indian Ocean to the Pacific Ocean, Con Dao soon monopolized the position of "crossroads" on a shipping route to the world and into the region. In 1868, Véret, an employee of the French East India Company, reminded its government to soon occupy 
Con Dao in order to establish international trading posts because it was necessary to be very close to the island if ships from China, Tonquin (Note 2), Macao, Manila, Cochinchina (Note 2), etc., wished to trade with India; and ships from Britain and Netherlands wishing to sail to the Chinese Waters also had to drop by here for both traveling from and to. The path was as convenient as the Strait of Sonde and Malacca. Moreover, Poulo Condor (Con Dao) has the same latitude as the southern Bantam - where the Dutch once built their trading posts (Jean Paul Morel 2010, p. 08). Not only dominating international maritime trade, Con Dao's position also helped to connect and shorten the journey to intra-Asian countries, as specifically from this island, merchant ships going back to the North would reach the Northeast Asia countries (Japan, Korea, China, Taiwan), while going to the south, they would see the Southeast Asian countries (Singapore, Indonesia, Malaysia, Thailand). At that time, Con Dao was both convenient for Westerners to establish trade relations with their neighbors in Cochinchina, and ideal to build military posts for the purpose of protecting its trading facilities, warehouses and wharves (Sir Francis Drake and William Dampier 1879).

The ideal natural condition of Con Dao is not only characterized by geographical features but also in the oceanic climate with sea breeze year-round. The harmonious combination of mountains, forests and the sea has created a green ecology and fresh air on the island in all four seasons. As described by French naval artist Jean Paul Morel: Poulo Condor (Con Dao) is the most suitable island for establishing a trading post because it is right at the estuary of Chenla (Note 3) with the width of six miles in circumference, there are three good harbors, many streams and a small river, which owns the most beautiful trees in the world (Jean Paul Morel 2010, p. 8). Owing to the diversity of forest flora, Con Dao is able to provide large-sized woody plants for the needs of repairing foreign merchant ships. "Con Dao is very plentiful in timber of all kinds and most of it is very useful in both construction and furniture making. There are also oily trees here, but the resin oil is very special in preserving other types of wood against insect damage... The wood here is rich, the stone has very large blocks, it is easy to separate into slabs, corals for calcination are immense, sand and clay, and especially a burnt red soil, very similar to Italian igneous soils that are suitable for mixing into perfect mortar" (Thống Đốc Nam Kỳ [Governor of Cochinchina], Symbol: IA2/024).

With this advantage, Con Dao has become a safe "sanctuary" for sea voyages from Europe to China. The sailors can even stay here in winter to repair the hull of the ship at the northern harbors with the abundant wood available (Charles B. Maybon. 2011, p. 107). Any stranded or wrecked ships are also refueled, have their sailepaired and can stop over here (Sir Francis Drake and William Dampier. 1879). While resting on the island to maintain and repair their vesselss, the sailors easily access the abundant local resources such as hairy crab, hawksbill sea turtle, giant clam, turbinidae or lobster. Gemstones used for jewelry also appear abundantly on the island, with many merchant ships came here to collect and sell them at their trading posts. Moreover, Con Dao can take us to prosperous southern lands (the south of Vietnam) and mainland Southeast Asia of Cambodia, Thailand and Myanmar with numerous mineral mines and abundant flora and fauna. Trinh Hoài Đức Gia Định thành thông chí (嘉定城通, Comprehensive Gazetteer of Gia Định Citadel) reminded the abundance of products of Con Dao: “[...] in the middle of the East Sea, from the mouth of Can Gio, it takes two days to sail to the sea in the east direction. The 100-mile large island has mountain fields where rice, corn, potatoes and beans are grown, but it is not much, so they often have to buy rice from Gia Dinh to have enough use. Local products here are horse and buffalo, mountain without leopard tigers.... The soldiers there often took bird's nest, tortoise's nest, turtles, cinnamon, fish sauce, and cochlea, then offered them according to the season, and the rest caught seafood such as fish, shrimp, to live. The areca fruit here is big, the areca nut's skin is pink, the taste is sweet and fragrant, until the beginning of spring, when the areca in Gia Dinh has no fruits, the areca here can be used, people bring them to sell at a very high price" (Trịnh Hoài Đức 1999, p.420). In the report of Levesque - Counselor of Civil Engineering Department sent to the Governor General of Indochina on May 28th, 1904 on the situation of Con Dao, he praised the natural resources here and affirmed clearly. Investment prospects for industries in the direction of making the most of the resources: "[...] First of all, logging. The types of wood used for construction grow on the island ... besides wood charcoal and granite are very plentiful and profuse" (Thống Đốc Nam Kỳ, Symbol: IA2/025).

Due to the convergence of many available advantages in nature (geographical location, climate, water resources, tropical forests, seafood and gemstones), Con Dao soon became a place to trade goods among merchants in the region with Dai Viet, China, Philippines, Malaysia and Thailand, and also provide maritime services to Western businessmen. From the end of the XVII century to the beginning of the XVIII century, the British East India Company and the French East India Company many times sent people to explore Con Dao for the purpose of building its own trading post system. The presence of two employees, Véret (French) and Williams Dampier (British) in Con Dao in 1686 and 1687 respectively for the purpose of field survey, mapping of the West - South Bay on the island shows the early start of Western countries in the occupation campaign for this key area (Nguyễn, Đ. T; 
Nguyễn, L. \& Hồ, S. T. 2010, p. 21). This is also historical evidence of the competition between the British and French forces in the expansion strategy of commodities trading at sea.

\subsubsection{Geo-politic and Military Position of Con Dao}

Not only being a "trade gateway", from the medieval period of world history, Con Dao has been also known as a key "military outpost". In the context that the international maritime industry was still limited in terms of vessels and was not capable of forecasting the weather well, the discovery of Con Dao as a stopover to shield from the elements with diverse terrain had vital significance for European military fleets on the way to Asia. The unique geo-political prominence of the island was shown quite clearly as the military outpost with an intertwined and completely closed system of forest and mountain. This "one of a kind" terrain played a strategic role in the construction of forts, strongholds and establishment of military obstacles to attack or defend proactively and unexpectedly. In addition, the diversity of terrain also creates favorable conditions for the construction of fortress, watchtower and observation stations, thereby forming a multi-layered military barrier both onshore and offshore. According to the description of French chief architect (Civil Engineering Department), Con Dao's bizarre shape resembling a giant rhino lying in the southwest - northeast direction is traces of upheavals the fire in the mountains. The main mountain range forms an arc to prevent the northwest wind. The other two straits, one in the northeast, one in the southwest, divide the wharf, 28 to 34 meters deep. If a big storm from the southeast can knock everything in the dock, ships can still rest assuredly lurk in the southeast, between the big Condore (Con Dao) and the small Condore, with a depth of 13 meters (Thống Đốc Nam Kỳ, Symbol: IA2/024).

With the advantage of being an archipelago consisting of many small islands, Con Dao is quite similar to a completely floating military base, creating contiguous tactical positions for arranging fire power. Besides, Con Dao is also less than 100 knots away from the mainland, so it is extremely convenient for moving and gathering army forces when necessary (VNU HCMC - USSH \& People's Committee of Ba Ria - Vung Tau Province. 2012, p. 277). In terms of the political and pivotal role of Con Dao, when the British explorer William Dampier came here in 1687 commented: The location of the island is very convenient to go to and from Japan, China, Manila, Tonquin and Cochinchina as well as all areas on the easternmost coast of the Indian continent whether through Malacca Bay or Sunda Bay between Sumatra and Java (Sir Francis Drake and William Dampier. 1879). Meanwhile, in Asia, all shipping routes from India to China must go through the Con Dao islands which are the gateway to Chenla, Champa (Note 4), Dai Viet (Note 5) (Lũ̃, H. N \& Giang, T. 1987, p. 24-25). The aforementioned advantages show that once a military base was established in Con Dao, the naval forces of the countries can both control the arterial sea route and control the gateway to Southeast Asia. Due to this great advantage, from the late XVII to XIX centuries, Western countries identified Con Dao as the most ideal location to be as springboard to invade Asian countries.

When compared to the islands of the Paracels, in the XVII century, Con Dao was still more prominent due to two key advantages: Firstly, it had fewer reefs and fine sand beaches, which cause shipwrecks; Secondly, its oceanic climate was temperate and cool, having fewer storms. Contrary to the tranquility and peace of Con Dao, scholar Dubois de Jancigny once described the Paracel Islands in the book "The world, history and description of all ethnic groups, religions, customs, practices: Japan, Indochina" (1850) as: A maze of intertwined islands, reefs and sand beaches stretching to hundreds of miles, which terrifies the seafarers. It is one of the most desolate places in the world (Adolphe Dubois de Jancigny. 1850, p. 555). Moreover, during the southwest and the northeast monsoons, foreign merchant ships along the Paracel Islands are often stranded there. History has recorded that French and Spanish expeditionary forces carrying 1,100 people on a European ship from Da Nang to Manila once crashed the reef near Tri Ton Island in the Paracel Islands (1860) (Nguyễn, Đ. H. 2017, p. 103). It can be seen that, although they are all rich islands, with fresh water streams and diverse sources of seafood, the safe terrain and stable climate of Con Dao have turned this land into "lucrative bait" for England and France to show their intentions of acquisition rights from the XVII century, while until the XIX century, the islands on the Paracel Islands were still had not garnered much interest, so when King Gia Long (Note 6) came to set a landmark to formally occupy the Paracel Islands (1816), there was still no one who wanted to compete for this land that only comprised reefs (Jean - Louis Taberd. 1837, p. 745). It is the overwhelming superiority of Con Dao's terrain in comparison to other islands and archipelagos that Western countries prioritize to this land in the service of national interests in Asia.

\subsection{Competition for Influence Among Western Countries in Con Dao}

Since the late of the XVII century, both England and France in turn left Tonquin due to new concerns about a well-known site in Cochinchina called "Poulo Condor" (Con Dao). The action of both Western countries came from the need to build trading posts and establish military bases in key areas in order to gain economic and political advantages in the strategy of expanding their sphere of influence outside Europe. 


\subsubsection{Demand for Establishing Trading Posts and Military Bases of Western Countries in Con Dao}

\section{- $\quad$ For England}

In terms of commerce, the British intended to build Con Dao into a transhipment terminal between Surat and China from the early XVIII century. That plan was expressed in the letter sent from Catchpoole - Chairman of Chusan trading post (China) to the Board of Directors of the British East India Company, in which it was stated that: This island (Con Dao) would soon become a trading intersection with China, from which ships could travel throughout the kingdom's trading ports to trade European products and to collect indigenous goods (Bruce. 1810, p. 580). Other documents of the British East India Company, especially the document made by the Board of Directors of the Company, and sent to the Chairman and sales managers in China on November 25, 1701 and December 24, 1701, having jointly agreed that: It was justifiable to establish a trading post in Con Dao and set up a fortress to protect this trade post (Bruce. 1810, p. 454).

During nearly four following decades (1744-1783), England often confronted France. This rivalry shifted from religious aspect to the economic and commercial aspects, whereby both empires were striving to dominate colonies in the Americas and Asia to expand their scope of exploitation and exchange of commodities. In this race, England needed to build a large-scale trading post system at places which had favorable natural conditions and that needed to be close to East Asia to easily access China. Only Con Dao could meet those exacting standards. From the strategic competition with France in maritime trade, British East India Company considered the occupation of Con Dao as its top priority because this island was a "trump card" to help England make a step ahead to approach the vast and highly potential commercial market in the Asia.

From the military point of view, since the War of the Grand Alliance (1688-1697). (Note 7) The British tended to be obsessed with the expansion and domination of French emperor Louis XIV in Europe. They, therefore, always wanted to proactively block the advance of the French army and constantly expanded their influence in the following 100 years. Thanks to the victory of the Seven Years' War against France (1756-1763), England firmly consolidated its colonial systems in India and North America, thereby officially becoming the leading colonial empire in the world. By the XIX century, the British Army controlled most of the countries located on essential maritime route from Europe to Asia, from East to West. In addition to commercial representative offices in Hong Kong (1842) and Guangzhou (1845), this empire also built an entire "colonial belt" stretching from the Strait of Malacca all the way to Canada and all of India. Despite owning such a vast territory, the British Empire still "ignored" Con Dao island.

With its military potential, the British were increasingly overhasty to occupy Con Dao out of fear that France would take over this land to compensate for their losses in India. Moreover, the British East India Company had landed on Con Dao since 1702 but eventually the British still had to flee due to a rebellion by the soldiers brought to the island to build forts. Therefore, in of the event that it could not quickly reoccupy Con Dao or losing Con Dao to France, the reputation of the British Empire would be greatly damaged. This was the main motive for British government to pay more attention to Con Dao, thereby demonstrating the military power and irreplaceable political role of the world's No.1 colonial power.

- $\quad$ For France

Regarding commerce, in the face of the British dominance in international trade activities, France did not flinch at all and wanted to quickly regain a balance based on the occupation of key islands on the East-West maritime route, from which demand for construction of a trade post or a warehouse on the French island derived. With its sharpness, the French East India Company determined that Con Dao was the only right choice because "it is located at the gateway of the Strait of Malacca, so it can conduct large-scale trading throughout the region, which will benefit French companies and cause losses for British and Dutch companies" (Charles B. Maybon. 2011, p. 107). More importantly, Con Dao is also considered as a "pivot point" in trading activities to control the maritime route from the Pacific Ocean to the Indian Ocean, ensuring capital exploitation and capital accumulation to enrich France. According to the analysis of Bishop Pigneau de Bé haine (Ba Da Loc) in the meeting with the French emperor Louis XVI (1787): Whichever country could set up military bases here (including Cochinchina and Con Dao) will have absolute advantage of completely blocking other countries, and will become the dominator of all trade from China to neighboring islands during wars (Ch. Gosselin. 1904, p. 36).

From the military perspective, the need to conquer Con Dao to establish bases for the French army became more urgent than ever. This urgency primarily rooted from the fact that France was under pressure and somewhat overwhelmed by the expansion of British influence in the Far East. After the defeat against England in the Seven Years' War (1756-1763), France realized that the biggest "hole" in its military system was the lack of a pivotal base to support and 
organize defenses when needed. Therefore, right after the discovery of Con Dao, Protais Leroux - a French merchant submitted to the Inspector General of the Ministry of Finance of this country a report on the island's strategic terrain, in which he maintained that if the French had owned the area before, the French East India Company would not have been captured by the British in China and Manila during the "the Seven Years' War" (Nguyễn, T. L. 2005, p. 104). Even after the war with Britain receded, King Louis XVI continued to receive reports from the French East India Company with the message: "If this area (Con Dao) had been occupied, then when war happened the French would be the lord. If the British occupied it first, we would be dependent on them all over the Asian coast" (Charles B. Maybon. 2011, p. 102).

Entering the XIX century, especially after the Opium War, the need to find a military base to anchor ships, gather squadrons and control the sea route through the Southeast Asia was so urgent that the French Minister of Foreign Affairs, Francois Guizot, issued a statement (1844) detailing that "France has no fulcrum in the region to anchor permanent boats to supply food, repair leaks and transfer the sick people to land. This is an unacceptable fact" (Nguyễn, T. L. 2005, p. 104). Although it was always driven by the need to build a military base having a pivotal role, France, with the nature of an usury empire, wanted to spend the lowest cost to achieve its goals. Considering such conditions, the country could not find a better location than Con Dao because the construction of a military base here "only required from 50 to 60 thousand Rupees with a ship and about 100 soldiers" (Charles B. Maybon. 2011, p. 107). With careful consideration of economic and political interests, France did not hesitate to confront England in the fight for Con Dao which lasted nearly two centuries (1686-1862).

\subsubsection{Competition Among Western Countries to Monopolize Con Dao}

\section{- $\quad$ England and France's conquest over Con Dao}

From the XV century to the XVI century, many European voyages visited Con Dao following the time when Marco Polo's fleet was sunk and drifted into these region. At the end of the XVII century, during the trade exchange with Cochinchina and Tonquin, the British East India Company and the French East India Company proactively sent its proxy to check and survey Con Dao's terrain with the intention to invade this island. In order to expand the influence on the East-West maritime route, the plan to build trading posts and military bases in Con Dao was initially promoted by Western countries by mapping the bays in the West.

Despite having been present in Con Dao since 1686, France lagged behind Britain in occupying this pivotal position. In 1702, the British East India Company landed on Con Dao, building a flagpole and fortress to assert its sovereignty. This event is recorded in many important British documents, specifically: The Dictionary "Academic Dictionaries and Encyclopedias" confirmed in June 1702, the British East India Company built a base in Con Dao (enacademic.com. Accessed on 17/3/2020); and the book "Tableau de la Cochinchine" published in 1862 by Cotembert and Rosny also affirmed: "In 1702, the British put on the main island of this archipelago a trading post" (Cortambert E. \& Rosny L. 1862, p. 6). To complete the construction of military structures in Con Dao early, the British East India Company brought with them 45 Europeans, seven to eight black Christian soldiers, and 15 to 16 Macassar men (mercenaries in Sulawesi province, Indonesia) (Lockyer Ch. 1711, p. 78). However, this illegal occupation faced opposition from the Annamites - the "true owner" of the island. (Note 8) In fact, the sudden rebellion of the Macassars against the British government in Con Dao (1705) had the arrangement and was under the command of the Nguyen Dynasty (Note 9) to protect the sovereignty and territorial integrity of Cochinchina (Nguyễn, Đ. T; Nguyễn, L. \& Hồ, S. T. 2010, p. 23). By cleverly putting a spy to the British force and inciting Macassar mercenaries to revolt due to illness and deprivation, Lord Nguyen forced the British to flee Con Dao after their first warehouse was set on fire and most Europeans here were killed (Colquhoun A.R. 1885, p. 353-354).

The Phủ biên tạp lục (撫邊雜, Miscellaneous Chronicles of the Pacified Frontier 1776) affirmed that: In 1702, the British East India Company poured troops into Con Dao and built a fortress. They open a trading business with other countries around the region: There are Chinese boats carrying bricks and tiles here in exchange for England goods because the capital is low but much profit. In order to against British, The Nguyen Lord Nguyen Phuc Chu organized the expulsion of British troops from the island, ensuring sovereignty over Con Dao: "In 1702, the British with 8 boats parked on Con Lon (Con Dao) island ... The exarch of Tran Bien palace, Truong Phuc Phan, reported this. The Lord sent him to find a way to eliminate them" (Lê Quy Đôn. 2017, p.2131).

This event was mentioned by Paulin Vial - Director of Internal Affairs Department later in Cochinchina: "This island is in front of the mouth of the Mekong River, a century ago occupied by the British, but abandoned after see can't keep it. One of their small garrisons, a short distance away from shore, on the long distance of merchant ships from China to Malaysia was the target of relentless attacks of the natives. An Nam kings are still the legal owners of that island" (Thống Đốc Nam Kỳ, Symbol: G/Divers: 3494). By the end of the XVIII century, besides the army garrisoned to 
exploit products, in Con Dao had a few inhabitants, mainly people who for special reasons could not live in the mainland, so they moved here. The whole family came here to start a career. During this period, there were about 60 families living in a small village in Con Dao. In the letter written on March 15, 1789, Governor General of Pondicherry stated in Con Dao: “... all Europeans have left and there are only less than 60 families living there” (Thống Đốc Nam Kỳ, Symbol: IA2 /028).

Although successfully pushing British troops out of Con Dao, more than 60 years later, the Nguyen Dynasty encountered difficulties due to the Tay Son peasant uprising (1771). With the defeat against the Tay Son's navy, the Nguyen Dynasty had to flee to Con Dao and call for French aid to regain the throne. As a result, in 1787, the Treaty of Versailles was signed by the Nguyen Dynasty with Count De Mantmarin (representing King Louis XVI of France). According to the content of the Treaty, the Nguyen Dynasty ceded to France the sovereignty of Da Nang seaport and the Con Lon archipelago (Con Dao) in exchange for four warships, 1200 infantrymen, infantrymen, 200 gunners, and 250 black African soldiers and ammunition for planning to attack the Tay Son (Tay Son dynasty) (Tạ, C. Đ. T. 1973, p. 182-183). Because feudalism in France was overthrown in the bourgeois revolution (1789), the Treaty of Versailles was not legally valid.

Since being knocked out of Con Dao, the British have refused to give up this strategic island. In the years 1780 and 1793, the British government still sent people to Con Dao to explore due to their fear of French troops landing on the island, especially after the Treaty of Versailles was signed. However, due to constant wrecking of their ships in this area, the East India Company could not continue to hold on to and had to leave Con Dao. Taking advantage of the time when Britain was in trouble, the French Government sent the ship La Cybèle to Da Nang (1817) to formally establish trade relation; at the same time reminding of the contents of the Treaty of Versailles. This was considered an important step for France to legalize the invasion of Vietnam (1858), thereby asserting the "legality" of sovereignty over the estuary of Han river and Con Dao. At the end of the attack on Da Nang and the occupation of Dinh Tuong Province, the French immediately raised the issue of conquering Con Dao as it was afraid that the British would soon return. At that time, in order to avoid the danger of "the archipelago is occupied by any western power" and "turning it into an observation fort that is very dangerous for us" (Tống Đốc Nam Kỳ, Symbol: IA2/1316). In November 1861, Bonard the French Fleet Admiral ordered an amphibious landing on Con Dao, Naval Lieutenant Lespès Sebastien Nicolas Joachim immediately made "The Statement of Sovereignty," officially fulfilling the goal of occupying this crucial position. "From this day, the French flag has been raised on the big Con Lon (Con Dao) island. This record of sovereignty was made in the presence of the officers of the Norzagaray fleet". (Tống Đốc Nam Kỳ, Symbol: G/Divers: 3494).

- Discussion on England and France's conquest over Con Dao

Firstly, within the competition for monopoly of Con Dao that spanned over two centuries, both England and France took advantage of every opportunity to make further steps beyond its competitor. However, in this process, the British colonists, in spite of invading early, still had to give up early on the Con Dao territory due to overconfidence, bad luck and impatience. Immediately after landing on the island (1702), the British were psychologically hasty and complacent quite early. They only focused on building the fort to "unilaterally" assert sovereignty without paying any attention to the Nguyen Dynasty's resistance. Moreover, the British government brought a small number of Europeans to the island, most of whom were Macassar mercenaries, who were always oppressed by the British and were subconsciously always willing to rebel. This subjective mistake plus the objective factor (unfavorable weather conditions) made the British colony the most "unlucky" in Con Dao. In the years 1778, 1780 and 1793, the British East India Company and the British navy kept coming to and leaving the island, mainly due to storms or boat damage. When facing these hardships, the British were so discouraged and impatient that they could not pursue their goal to the end. It was a fact that Lord Macartney - the special ambassador of the British King and the expedition were frightened and hurriedly left Con Dao because of a mere anchor breakage accident (May 1793) (J. C Demariaux. 1944).

Secondly, the Nguyen Dynasty played a key role in the outcome of abandoning Con Dao by England and the reoccupying Con Dao by France. After being expelled from Con Dao by Macassar soldiers (1705), in the period of 1706-1707, the British colonialists plotted to take back the island, but they did not dare to stay near the mountains and set up streets near the coast. However, at this time, a large number of British soldiers died, partly because they could not tolerate water and soil conditions, and most of them were killed by Lord Nguyen (Dai Viet) (Hồ, B. T. 2019). Meanwhile, because of difficulties in suppressing a peasant uprising in the country, the Nguyen Dynasty signed the Treaty of Versailles with France. This was the act of "aiding and abetting" the French army to later claim Con Dao.

Thirdly, the French came after the British but they were "patient" and "made great efforts" in the exploration and then in monopolizing Con Dao. The process of exploration, survey, occupation and then re-occupation over Con Dao by the 
French government went on continuously for centuries. From the XVII century, the French East India Company started to draw its eyes to Con Dao with the intention of turning this place into its own trading posts and military bases. In the period 1765-1769, the French invaded Con Dao for the first time but then withdrew. After signing the Treaty of Versailles with the Nguyen Dynasty (1787), France used this treaty as an important basis to retake Con Dao for the second time. Along with the completed invasion over the south of Vietnam, France officially "pulled the carpet" from under England's feet and monopolized Con Dao based on "legal" pressure with two documents: the French Fleet Admiral - Louis Adolphe Bonard signed the decision to establish Con Dao prison (February 1862) and France urged and proceeded with the successful execution of the "Treaty of Nham Tuat year (Year of the Dog)" or "The Treaty of Saigon" with the Nguyen Dynasty, detailing the division of three eastern provinces and Con Dao for France (June 1862) (Mark W. McLeod. 1991, p. 54). This was achieved after France had competed with England and fought with the Nguyen Dynasty. All of this was for the goal of acquiring Con Dao to serve the economic and political benefits of Western countries since the XIX century.

In the strategic vision of French merchants and politicians, Con Dao played a pivotal role in helping the country to control the maritime route from the Pacific to the Indian Ocean and at the same time guaranteeing the monopoly over capitalist exploitation in Asia. Despite the initial perception, after the official occupation of Con Dao (1861), France changed its plan to build this spot into a trading post or military base due to limited financial resources. In fact, during the first occupation of Vietnam, France encountered various difficulties due to boisterous movements of the colonized people. The security situation in the regions newly occupied by the French was also unstable due to gambling, drinking, robbery and murder. In this context, the persecution, arrest and detention of the rebels against France and the French protectionist policy in Vietnam left the mainland prison system overwhelmed. To resolve immediate difficulties, France urgently built a large-scale prison to strengthen its domination in the colony. At that time, Con Dao was a geographical location far from the mainland, and with its abundant resources, Con Dao was considered to be the most suitable location by the French to set up prisons and apply apply a hard labor regime - using the labor of prisoners to exploit products on the island, thereby, enriching France. With that awareness, Governor Louis Adolphe Bonard signed a decision to establish Con Dao prison in 1862. Up until 1954, Con Dao officially became the "hell on earth" of the patriotic Vietnamese and the model prison in the colonial prison system of France in Vietnam and abroad. When the US replaced the French presence in Vietnam, Con Dao's strategic geographical position was further requisitioned by this superpower for the purpose of imprisoning Vietnamese Revolutionary soldiers. Con Dao continued to become a typical prison in the US imperial prison system in Southern Vietnam until the XX century.

\section{Conclusion}

Owing to a strategic position with the convergence of favorable natural factors, Con Dao soon fell in the sights of English and French forces in the process of developing foreign trade and opening foreign trade activities to extend their political sphere of influence in China and India. The commercial exchange with both Cochinchina and Tonquin of Vietnam since the late XVII century has created opportunities for Western countries to initially approach this land of vast potential with the intention of taking it over and monopolizing it. History records that England and France took turns to set foot on Con Dao and created an uncompromising competition for two centuries, commencing from the topographic survey of the French (1686), the "illegal" landing by the British (1702) and a series of subsequent reoccupations by both countries.

For France, the ambition to establish a trading post on Con Dao to link trade with Guangzhou and Tonquin and the plan of constructing a military base to serve as a springboard to acquire Southeast Asian countries was repeatedly interrupted, and even broken, by the British presence in Con Dao. Even so, France always took the initiative due to the weakness and pessimism of the East India Company and the French "reinforcements" of the Nguyen Dynasty via the Treaty of Versailles. Thanks to the location of the trade route passing through the Strait of Malacca, the island has always been seen in France's history as an important determinant of its success from the Seven Years' War in Europe to the acquisition of Indochina in Asia.

After a long time of being exploited and occupied by foreign countries, Con Dao has become one of the most beautiful and vastly potential islands in the world, playing the role of a "shield" to protect important seaports and key economic areas in the South of Vietnam. Con Dao's strategic geographical position is now effectively promoted by local authorities and residents turning it into a "sea and island tourism belt" - connecting the country's Eastern waters with the Gulf of Thailand. Considering this new position, Con Dao is no longer just a tragic history but is rising in the middle of the sea every day to prove its position of economic-political "frontline position" on Asia - Europe maritime routes from XVII century and a strategic spot to promote the process of development and integration of Vietnam in the XXI century. 


\section{References}

Adolphe, D. D. J. (1850). L'univers: Histoire et description de tous les peuples, Japon, Indo-Chine, Empire birman (ou Ava), Siam, Annam (ou Cochinchine) (p. 555). Published by Firmin Didot Freres, Paris.

Bruce. (1810). Annals of the honorable East-India company: from their establishment by the charter of queen Elizabeth, 1600, to the union of the London and English East-India companies (Vol. 3, p. 454, p. 580) London: Black, Parry, and Kingsbury.

Colquhoun, A. R. (1885). Amongst the Shans (pp. 353-354). New York: Scribner \& Welford.

Cortambert, E., \& Rosny, L. (1862). Tableau de la Cochinchine (p. 6). Paris: Armand Le Chevalier.

Đảo, N. T. C. (1987). The party history research board of ba ria vung Tau-Con Dao special zone. Truth National Political Publishing House, Hanoi.

Demariaux, J. C. (1944). Indochine Hebdomadaire Illustré, No. 196, 197.

Demariaux, J. C. (1956). Les secrets de Iles de Poulo Condore (le grand bagne indochinois). J. Pyonnet et Cie, Paris.

Đôn, L. Q. (2017). Phủ biên tạp luc (撫邊雜, Miscellaneous Chronicles of the Pacified Frontier 1776). Ha Noi: Van hoaThong tin.

Drake, S. F., \& Dampier, W. (1879). A voyage around the world. Published by Li-quor Tea Company, London.

Gosselin, Ch. (1904). L'empire d'Annam, librairie académic Didier (p. 36). Paris.

Hồ, B. T. (2019). Lord Nguyen Defending Seas and Islands, Driving Europeans away. Retrieved March 15, 2020, from https://trithucvn.net/van-hoa/quan-chua-nguyen-bao-ve-bien-dao-xua-duoi-nguoi-au-chau.html

Institute of Geography, Vietnam Academy of Science and Technology. (2010). Kỷ yếu Hội nghị Khoa học Địa lý Toàn quốc lần thứ 5. Proceedings of the 5th National Scientific Conference on Geography (pp. 1021-1022). Hanoi.

Lê, H. P. (2006). Nhà tù Côn đảo (Con Dao Prison). National University Publishing House Ho Chi Minh City.

Li, T. (1998). Nguyen Cochinchina - Southern Vietnam in the Seventeenth and Eighteenth Centuries. Ithaca, N.Y.: Cornell University Press.

Lockyer, Ch. (1711). An Account of the Trade in India (p. 78). London: Samuel Crouch.

Lũ, H. N., \& Giang, T. (1987). Vung Tau Scenic Land (pp. 24-25). Cultural Publishing House.

Maybon, C. B. (2011). Nhũng người châu Âu ở nước An Nam (pp. 102-107). World Publisher, Hanoi.

McLeod, M. W. (1991). The Vietnamese Response to French Intervention (1862-1874) (p. 54). The Green Wood Publishing Group.

Morel, J. P. (2010). Relation Abrégée des Voyages Fraits Par Le Sieur Poivre de 1748 à 1757: Voyages de Pierre Poivre (1748-1757) (p. 8).

Nguyễn, D. H. (2017). The Wreck of the Europeans in Paracel Islands. Journal of Research and Development, 4(138), 103.

Nguyễn, Đ. T. (1996). The Island of Monuments and Landmarks. People's Army Publishing House, Hanoi.

Nguyễn, Đ. T., Nguyễn, L., \& Hồ, S. T. (2010). Lịch sủ nhà tù Côn Đảo (1862-1975) (History of Con Dao Prison (1862-1975)) (pp. 21-23). Ho Chi Minh City General Publishing House.

Nguyễn, M. D. (2006). Regarding the Commercial Activities of the French East India Company with Dai Viet - the Second Half of the XVII Century to the Middle of the XVIII Century. Journal of Historical Studies, (9).

Nguyễn, T. L. (2005). Dai Viet Diplomatic Relations in Nguyen Dynasty (p. 104). Vietnam Culture and Information Publishing House, Hanoi.

Nguyễn, T. L. (2009). Islands in the Southwest Sea. Journal of Research and Development, Hue, (4).

Nguyễn, V. D. (2009). France-Vietnam relations before 1858. Printed in the 220 years of the French Revolution (1789-2009 and Vietnam - France Relations in History). National Political Publishing House, Hanoi.

NHBND (National History Bureau of the Nguyễn Dynasty). (1993). 大南正編列傳, Official Compilation of Đại Nam ’s History. Huế: Thuận Hóa.

NHBND (National History Bureau of the Nguyễn Dynasty). (2004). Đại Nam thục lục (大南定錄, Veritable Records 
of the Great South) (Vol. 2, 3\&4). Hanoi: Giáo dục.

NHBND (National History Bureau of the Nguyễn Dynasty). (2007). Khâm định Đại Nam Họi điển sư lệ tục biên (欽 定大南會典事例續編, Royal compilation on Historical Facts and Events in Đại Nam - Extension) (Vol. 6). Hanoi: Social Sciences.

NHBND (National History Bureau of the Nguyễn Dynasty). (2012). Đại Nam nhất thống chí (大南一統志, Đại Nam Comprehensive Encyclopaedia). Hanoi: Lao động.

Phạm, X. (2012). Côn Đảo Pháo đài tiền tiêu đông nam Tổ quốc (Con Dao - Southeastern Fortress of the Nation). Yesterday and Today Review, (402).

Phan, H. C. (1992). Lịch triều hiến chuoong loại chí (歷朝憲章類誌, Treaties of the Successive Dynasties) (Vol. 1). Hanoi: Social Sciences.

Phan, H. L. (2017). Vùng đất Nam Bộ quá trình hình thành và phát triển (The Southern region of the process of formation and development). Hanoi: National Politics.

Phan, K. (1969). Việt sử xú Đàng Trong (Vietnamese History in Cochinchina). Literature Publishing House, Hanoi.

Tạ, C. Đ. T. (1973). Lịch sủ Nội Chiến Việt Nam 1771- 1802 (History of Vietnam Civil War 1771- 1802) (pp. 182-183). Saigon History Publishing House.

Taberd, J.-L. (1837). The Geography of Cochin China. Journal of the Asiatic Society of Bengal, 6(2), 745.

Thạch, P., \& Nguyen, T. M. (2005). Địa chí Bà Rịa-Vũng Tàu (The Geography of Ba Ria - Vung Tau). Social Sciences Publishing House, Hanoi.

The National Archives and Records Management. (2010). Summary contents of the texts "Chau ban" of the Nguyen Dynasty. Publishing House of Information and Culture, Hanoi.

Thống, Đ. N. K. (n.d.). Letter dated 10-7-1961 of the Minister of the French Navy and Colonies sent to Charner admiral (the commander in chief of the French expeditionary force in Indochina). National Archives Center II, Symbol: IA2 / 1316.

Thống, Đ. N. K. (n.d.). National Archives Center II, Symbol: G/Divers: 3494.

Thống, Đ. N. K. (n.d.). Report of chief architect (unclear signature) of the Civil Engineering Department dated August 17th, 1874 on topography and resources of Con Dao. National Archives Center II; Symbol: IA2 / 024.

Thống, Đ. N. K. (n.d.). Report of Levesque - Counselor of Civil Engineering Department sent to the Governor General of Indochina on May 28th, 1904 on the situation of Con Dao. National Archives Center II; Symbol: IA2/025.

Thống, Đ. N. K. (n.d.).The letter written on March 15, 1789 to the Count Luydécnơ in Paris, Governor General of Pondicherry. National Archives Center II; Symbol: IA2/028.

Trần, Đ. T. (2012). Biển đảo Việt Nam, tài nguyên vị thế và nhũng kỳ quan địa chất, sinh thái tiêu biểu (Vietnamese Sea and Islands - Position Resources, and Typical Geological and Ecological Wonders). Publishing House for Science \& Technology. Vietnam Academy of Science and Technology, Hanoi.

Trần, K. H., \& Bùi, V. Q. (2011). Biên khảo Nhà tù Guyane và nhũng câu chuyện về nguời An Nam (1862-1953) (Editing of Guyane Prison and Stories of Annamese (1862-1953)). National Political Publishing House), Hanoi.

Trịnh, H. Đ. (1999). Gia Định thành thông chí (嘉定城通志, Gazetteer of Gia Định Citadel). Hanoi: Giáo dục.

Trương, B. C. (2011). French diplomatic activities aimed at strengthening the base in Cochinchina (1862-1874). World Publishing House, Hanoi.

Vnu Hcmc - Ussh (Vietnam National University - Ho Chi Minh City - University of Social Sciences and Humanities)., \& People's Committee of Ba Ria - Vung Tau Province. (2012). Con Dao - 150 years of struggle, construction and development (1862-2012) (p. 277). National Political Publishing House - Truth Publishing House, Hanoi.

Yele, H. (1921). The Book of Ser Marco Polo, Lon don, Murray (Vol. 2).

Zhou, D. G. (2017). Chân Lạp phong thổ ký (Notes on the Customs of Chenla). Hanoi: Thế giới. 


\section{Notes}

Note 1.East Sea, sometimes referred to as "South China Sea".

Note 2. In Vietnam (1627-1672), the Trinh and Nguyen families fought 7 times without any results, so the war would be stopped and the Gianh river was considered as a boundary to demarcate the territory: the North of Gianh river belonged to Le King - Trinh Lords was called Dang Ngoai (whose capital was Dong Kinh, the Westerners called it as Tonquin or Tonkin), the South of the Gianh River belonged to Nguyen Lord called Dang Trong (Cochinchina).

Note 3. Chenla was the first state of the Khmer to exist between 550 and 802 on the southern part of the Indochinese peninsula including Cambodia and some southern provinces of Vietnam today.

Note 4. Champa is an ancient country which existed independently and continuously over the period from 192 to 1832. The area of Champa at its widest range extends from the Hoanh Son mountain range, from Quang Binh Province in the north to Binh Thuan Province in the south and from the East Sea sometimes referred to as the East Sea to the western mountains of Laos today.

Note 5. Dai Viet is the Vietnamese national name that existed in two periods from 1054 to 1400 and from 1428 to 1805.

Note 6. Gia Long (1802-1820) was the first Emperor of the Nguyen dynasty of Vietnam

Note 7. This was a great war in the late 17th century between King Louis XIV of France and the Great Alliance: King William III of England - Netherlands, Leopold I of the Roman Empire, King Carlos II of Spain, Victor Amadeus II of Savoy and the dukes of Rome.

Note 8. Annam is the old name of Vietnam, popular in the period from 679 to 1945 . Vietnamese people were referred to as Annamites.

Note 9. Nguyen Dynasty was the last monarchy in Vietnamese history.

\section{Copyrights}

Copyright for this article is retained by the author(s), with first publication rights granted to the journal.

This is an open-access article distributed under the terms and conditions of the Creative Commons Attribution license (http://creativecommons.org/licenses/by/4.0/). 